\title{
Analisis dan Perancangan Sistem Informasi Kartu Nelayan Untuk Masyarakat Kabupaten Bangka Barat Berbasis Desktop Studi Kasus: Dinas Kelautan dan Perikanan Kabupaten Bangka Barat
}

\author{
Kiswanto $^{[1]}$, Andi $^{[2]}$ \\ STMIK Atma Luhur, Jl. Jend. Sudirman, Selindung, Pangkalpinang, Kep. Bangka Belitung \\ Program Studi Sistem Informasi ${ }^{[1][2]}$ \\ Kiswanto@atmaluhur.ac.id ${ }^{[1]}, 1222500056 @$ andi.atmaluhur.ac.id ${ }^{[2]}$
}

\begin{abstract}
Abstrak- Dinas Kelautan dan Perikanan are elemental Local Government executor at naval area and fishery and on hands to Regent via Region secretary. Dinas Kelautan dan Perikanan having task is region autonomy at naval area and fishery covers sumberdaya's management fishery and naval, coast and isle in order to perform pembantuan's decentralisation and task task. Fishery area and Catches is one of area in on duty naval and fishery that services in makings and Fisherman Card exploit. Therefore fishery Area and Catches to have gets to give prima service and can in cards harnessed management fisherman to fishermen on the nose utilised and correct objective. One of effort which can be done is increase and do harnessed information system repair fisherman card with computerised and integrated system to be able to give information in point and accurate basal succeeding decision making.
\end{abstract}

Kata kunci :

Information System Fisherman Card Exploit Society, Metodologi Berorientasi Objek, Unifield Modelling Language (UML)

\section{Pendahuluan}

Perkembangan teknologi informasi yang sedemikian cepatnya telah membawa dunia memasuki era baru yang lebih cepat dari yang pernah dibayangkan sebelumnya. Sejak ditemukannya komputer sebagai alat pengolah data sampai dengan era Internet saat komputer menjadi senjata utama dalam berkompetisi. Sistem informasi merupakan sekumpulan komponen yang saling berhubungan, mengumpulkan, memproses, menyimpan, dan mendistribusikan informasi untuk menunjang pengambilan keputusan dan pengawasan dalam suatu organisasi.

Perkembangan dunia sistem informasi pada saat ini sudah sedemikian pesat dan merambah ke berbagai sisi kehidupan manusia. Perkembangan yang demikian tersebut didukung oleh tersedianya perangkat keras maupun perangkat lunak yang semakin hari semakin hebat kemampuannya. Selain menunjang proses pengambilan keputusan, koordinasi, dan pengawasan, sistem informasi juga dapat membantu manusia dalam menganalisis permasalahan, menggambarkan penguatan usaha kepada nelayan sehingga lebih tepat sasaran. Selama ini pemerintah masih kesulitan dalam menentukan katagori nelayan miskin/lemah termarginalisasi butuh perhatian yang sangat serius, sehingga perlu melakukan monitoring agar bantuan terhadap nelayan dapat dijangkau dan lebih fokus tepat sasaran.

Berdasarkan uraian diatas, maka penulis akan mengembangkan sebuah sistem informasi yang dapat membantu dan mempermudah bidang tangkap melakukan pemanfaatan kartu nelayan yang lebih efektif dan efisien. Sehingga dalam hal ini penulis memilih judul "Analisis dan Perancanagan Sistem Informasi Kartu Nelayan Untuk Masyarakat Bangka Barat Berbasis Application Desktop Studi Kasus: Dinas Kelautan dan Perikanan Kabupaten Bangka Barat".

\section{LANDASAN TEOR}

\section{A. Sistem Informasi}

Menurut Indrajani, Sistem Informasi adalah sekelompok elemen yang saling berhubungan atau berinteraksi hingga membentuk satu-kesatuan [4]. Menurut Jogiyanto H.M., tujuan dari sistem informasi adalah menghasilkan informasi (Information) dari bentuk data yang diolah menjadi bentuk yang berguna bagi para pemakainya [3]

Kegiatan sistem informasi meliputi:

1. Input, menggambarkan suatu kegiatan untuk menyediakan data untuk diproses. 
2. Proces, menggambarkan bagaimana suatu data diproses untuk menghasilkan suatu informasi bernilai tambah.

3. Output, suatu kegiatan untuk menghasilkan laporan dari kegiatan proses.

4. Penyimpanan, suatu kegiatan untuk memelihara dan penyimpanan data.

5. Control, suatu aktivitas untuk menjamin bahwa sistem informasi tersebut berjalan sesuai dengan yang diharapkan.

Fokus utama sistem informasi berbasis komputer adalah untuk aplikasi perkantoran (Office Automation), dimana komputer memiliki porsi semakin berarti untuk aplikasi Sistem Informasi Akuntansi (SIA), Sistem Informasi Manajemen (SIM), dan Decision Support System (DSS).

\section{B. Konsep Basis Data}

Basis data sendiri dapat didefinisasikan dalam sejumlah sudut pandang seperti:

1. Himpunan kelompok data (arsip) yang saling berhubungan yang diorganisasi sedemikian rupa agar kelak dapat dimanfaatkan kembali dengan cepat dan mudah.

2. Kumpulan data yang saling berhubungan yang disimpan secara bersama sedemikian rupa dan tanpa pengulangan (redundasasi) yang tidak perlu, untuk memenuhi berbagai kebutuhan.

3. Kumpulan file/tabel/arsip yang saling berhubungan yang disimpan dalam media penyimpanan elektronis.

\section{Perancangan Sistem}

Menurut Tata Sutabri, perencanaan sistem informasi yang merupakan terjemahan dari Information System Planning (ISP), menjelaskan bagaimana menerapkan pengetahuan tentang sistem informasi ke dalam organisasi agar dapat terus maju dan eksis bila organisasi berkembang sesuai dengan teknologi dan teori organisasi modern. Namun, hal ini tidak berarti bahwa sistem informasi dan teknologi informasi merupakan suatu hal yang kaku. Sistem informasi dapat dibentuk sesuai dengan kebutuhan organisasi [1].

Oleh karena itu, untuk dapat menerapkan sistem yang efektif dan efisien diperlukan perencanaan, pelaksanaan, pengaturan dan evaluasi sesuai keinginan dan nilai masing-masing organisasi. Tujuan dari sistem yang efektif dan efisien tidak lain adalah untuk mendapatkan keunggulan dalam kompetisi.

\section{Waterfall}

Model waterfall ini sebenarnya adalah "Linear Sequential Model", yang sering dsebut juga dengan "classic life cycle" atau model waterfall. Waterfall atau air terjun adalah model yang dikembangkan untuk pengembangan perangkat lunak, membuat perangkat lunak. Model berkembang secara sistematis dari satu tahap ke tahap lain dalam model seperti air terjun. ${ }^{[3]}$

\section{Waterfall model}

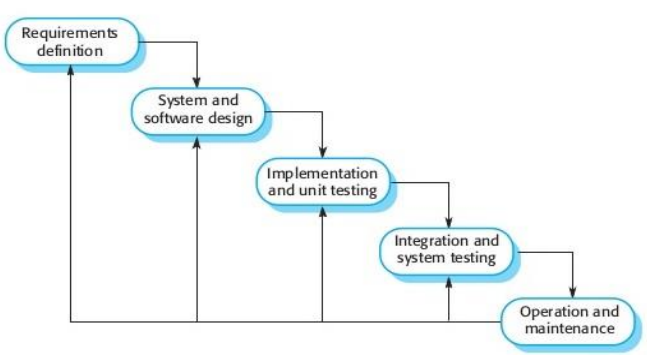

Gambar 1. Model Waterfall

Berikut adalah penjelasan dari tahap-tahap yang dilakukan di dalam model ini menurut Pressman :

1. Requirements Definition

Seluruh kebutuhan software harus bisa didapatkan dalam fase ini, termasuk didalamnya kegunaan software yang diharapkan pengguna dan batasan software. Informasi ini biasanya dapat diperoleh melalui wawan cara, survei atau diskusi. Informasi tersebut dianalisis untuk mendapatkan dokumentasi kebutuhan pengguna untuk digunakan pada tahap selanjutnya.

2. System and Software Design

Tahap ini dilakukan sebelum melakukan coding. Tahap ini bertujuan untuk memberikan gambaran apa yang seharusnya dikerjakan dan bagaimana tampilannya. Tahap ini membantu dalam menspesifikasikan kebutuhan hardware dan sistem serta mendefinisikan arsitektur sistem secara keseluruhan.

3. Implementation and Unit Testing

Dalam tahap ini dilakukan pemrograman. Pembuatan software dipecah menjadi modul-modul kecil yang nantinya akan digabungkan dalam tahap berikutnya. Selain itu dalam tahap ini juga dilakukan pemeriksaaan terhadap modul yang dibuat, apakah sudah memenuhi fungsi yang diinginkan atau belum.

4. Integration and System Testing

Di tahap ini dilakukan penggabungan modul-modul yang sudah dibuat dan dilakukan pengujian ini dilakukan untuk mengetahui apakah software yang dibuat telah sesuai dengan desainnya dan masih terdapat kesalahan atau tidak.

5. Operation and Maintenance

Ini merupakan tahap terakhir dalam model waterfall. Software yang sudah jadi dijalankan serta dilakukan pemeliharaan. Pemeliharaan termasuk dalam memperbaiki kesalahan yang tidak ditemukan pada langkah sebelumnya. Perbaikan implementasi unit sistem dan peningkatan jasa sistem sebagai kebutuhan baru. ${ }^{[4]}$

\section{E. Unified Modelling Language (UML)}

Unified Modelling Language (UML) adalah sebuah "bahasa" yang telah menjadi standar dalam industri untuk visualisasi, merancang dan mendokumentasikan sistem piranti lunak. UML menawarkan sebuah standar untuk merancang model sebuah sistem. ${ }^{[5]}$ 


\section{F. Perancangan Berorientasi Objek}

Tahap-tahap metodologi berdasarkan Sistem Development Life Cycle (SDLC) digunakan dengan memperhatikan karakteristik khusus berorientasi objek, diantaranya adalah :

\section{1) Analisis}

Analisis berorientasi objek dimulai dengan menyatakan suatu masalah, analis membuat model situasi dari dunia nyata, menggambarkan sifat yang penting. Analis harus bekerja dengan pihak yang membutuhkan sistem untuk memahami masalah tersebut. Model analisis adalah abstraksi yang ringkas dan tepat dari apa yang harus dilakukan oleh sistem, dan bagaimana melakukannya. Objek dalam model harus merupakan konsep domain dari aplikasi, dan bukan merupakan implementasi komputer seperti struktur data. Model yang baik harus dipahami dan ditanggapi oleh ahli aplikasi. Empat kesulitan yang merupakan gangguan utama sistem adalah memahami problem domain, komunikasi antara pihak yang berkaitan, perubahan kontinyu, dan reuse (penggunaan kembali).

\section{2) Desain}

Desain Berorientasi Objek atau Object Oriented Design (OOD) merupakan tahap lanjutan setelah Analisis Berorientasi Objek dimana tujuan sistem diorganisasikan ke dalam sub-sistem berdasar struktur analisis dan arsitektur yang dibutuhkan. System Designer menentukan karakteristik penampilan secara optimal, menentukan strategi memecahkan masalah, dan menentukan pilihan alokasi sumberdaya. Sebagai contoh, System Designer mungkin menentukan perubahan pada screen untuk workstation yang memerlukan kecepatan serta resolusi lebih tinggi. Desain model berdasarkan model analisa tetapi berisi detail implementasi. Fokus dari object design adalah perencanaan struktur data dan algoritma yang diperlukan untuk implementasi setiap kelas. Objek domain aplikasi dan objek domain komputer dijelaskan dengan menggunakan konsep dan notasi berorientasi objek yang sama.

\section{3) Implementasi}

Kelas, objek, dan relasinya dikembangkan dalam tahap pembuatan desain objek yang pada akhirnya diterjemahkan ke dalam bahasa pemrograman, basis data, dan implementasi perangkat keras. Hal yang penting dalam tahap implementasi adalah mengikuti penggunaan perangkat lunak yang baik.

Diagram - diagram UML yang digunakan penulis dalam merancang sistem berorientasi objek adalah :

1) Activity Diagram

Activity Diagram adalah Sebuah diagram alur kerja yang menjelaskan berbagai kegiatan pengguna (atau sistem), orang yang melakukan masing-masing aktivitas, dan aliran sekuensial dari aktivitas-aktivitas tersebut.
2) Use Case Diagram

Use Case Diagram adalah salah satu jenis diagram pada UML yang menggambarkan interaksi antara sistem dan aktor, use case diagram juga dapat men-deskripsikan tipe interaksi antara si pemakai sistem dengan sistemnya.

3) Package Diagram

Package diagram yaitu salah satu jenis diagram pada UML digunakan untuk mengelompokan kelas dan juga menunjukan bagaimana elemen model akan disusun serta mengambarkan ketergantungan antara paket-paket.

4) Class Diagram

Class diagram yaitu salah satu jenis diagram pada UML yang digunakan untuk menampilkan kelas-kelas maupun paket-paket yang ada pada suatu sistem yang nantinya akan digunakan.

5) Deployment Diagram

Deployment Diagram yaitu salah satu diagram pada UML yang menunjukan tata letak suatu sistem secara fisik, dapat juga dikatakan untuk menampilkan bagian-bagian software yang terdapat pada hardware dan digunakan untuk menerapkan suatu sistem dan hubungan antara komponen hardware.

6) Sequence Diagram

Sequence Diagram yaitu adalah satu jenis diagram pada UML yang menjelaskan interaksi objek yang berdasarkan urutan waktu, sequence diagram juga dapat menggambarkan urutan atau tahapan yang harus dilakukan untuk dapat menghasilkan sesuatu seperti pada use case diagram.

\section{G. Microsoft visio 2007}

Microsoft visio 2007 adalah salah satu program yang dapat digunakan untuk membuat diagram, aplikasi ini menyediakan banyak fasilitas pembuatan diagram untuk mengambatkan informasi dari sistem, dari penjelasan dalam bentuk teks menjadi bentuk diagram gambar disertai penjelasan singkat. untuk mempelajari Microsoft visio dan mengambarkan diagram, anda tidak membutuhkan teknik yang sangat tinggi karena visio sangat mudah untuk digunakan dan diimplementasikan.

\section{H. Visual Basic 2008}

Visual Basic berasal dari singkatan BASIC (beginner's All-Purpose Symbolic Instruction Code) yang dibuat oleh Profesor Jhin Kemeny dan Thomas kurs dari Darmont pada pertengahan tahun 1960. Perintah-perintah bahasa program yang digunakan adalah bahasa inggris, dengan tujuan dapat mempermudah pemrograman yang menggunakan bahasa pemrograman ini.

Bahasa pemrograman BASIC dikembangakan dengan nerbagai bentuk diantaranya adalah Microsft QBASIC, QUICCKBASIC, GWBASIC, IBM BASIC, dan Apple BASIC. Apple BASIC dikembangkan oleh Steve Wozniak, seorang karyawan Hewlett-Packard yang pada akhirnya pada bulan April 1976 secara resmi membentuk perusahaan Apple Komputer. 
Kemudian menggunakan bahasa pemrograman BASIC akhirnya mendorong Microsoft untuk mengembangkan bahasa BASIC dengan GUI-BASED. Graphical User Interface membuat pengguna bahasa Basic semakin senang dengan komponen yang disediakan oleh pembuatnya, mereka merasakan kemudahan dalam menggunakan dan membuat program dengan bahasa yang berbasis visual.

\section{Microsoft Access 2007}

Microsoft Access merupakan salah satu produk database engine dari Microsoft yang sudah sangat dikenal. Dari produkproduk Access versi sebelumnya, maka dapat kita simpulkan bahwa Access merupakan sebuah database engine yang walaupun sederhana namaun dapat diandalkan dan sangat memadai untuk kebutuhan studi atau kebutuhan bisnis dengan skala kecil menengah.

Kali ini Microsoft kembali mengeluarkan versi terbaru dari produk ini, yaitu Microsoft Access 2007, yang merupakan produk revolusioner terutama dari segi antarmuka yang sama sekali baru dan berbeda jika dibandingkan seri Access sebelumnya, antarmuka baru ini tentu saja memberikan banyak kemudahan bagi pemakai, terutama bagi para pemakai yang baru memakai produk Microsoft Access atau mereka yang tidak terbiasa dalam menggunakan program-program database sebelumnya.

\section{Metodologi Penelitian}

\section{A. Model Waterfall}

Aktifitas pengembangan sistem yang penulis lakukan sesuai dengan model pengembangan perangkat lunak di atas adalah:

\section{1) Perencanaan Sistem}

Pada tahap ini ada beberapa hal penting yang perlu dilakukan dalam pembuatan sistem inventory ini yaitu pengumpulan data untuk menggali informasi yang dibutuhkan untuk membuat Analisis dan Perancanagan Sistem Informasi Kartu Nelayan Untuk Masyarakat Bangka Barat Berbasis Application Desktop Studi Kasus: Dinas Kelautan dan Perikanan Kabupaten Bangka Barat. Adapun metode pengumpulan data yang penulis gunakan adalah sebagai berikut :

a) Wawancara

Melakukan komunikasi tanya jawab secara langsung dengan karyawan ASIA Group Pangkalpinang mengenai sejarah terbentuknya ASIA Group Pangkalpinang, struktur organisasi, serta sistem inventory yang berjalan di ASIA Group Pangkalpinang.

\section{b) Observasi}

Dalam hal ini penulis langsung melihat atau mengadakan pengamatan ke bagian-bagian yang ada hubungannya dengan sistem informasi inventory sparepart sekaligus pengumpulan dokumen-dokumen yang digunakan.

\section{c) Studi Pustaka}

Menggunakan beberapa buku sebagai referensi, untuk memperoleh penjelasan yang bersifat teori yang berhubungan dengan masalah yang diteliti.

d) Studi Literatur

Studi literatur digunakan untuk mengumpulkan data dari penelitian terdahulu, pembelajaran dari berbagai macam literatur dan dokumen seperti buku, jurnal dan teori-teori yang mendukung penelitian, tools yang akan digunakan dan data penunjang lainnya yang berkaitan dengan sistem informasi penjualan berbasis web.

\section{2) Analisis Sistem}

Di dalam analisis sistem terdapat beberapa langkah dasar yang harus dilakukan adalah sebagai berikut :

a) Activity Diagram

Bagian dari penggambaran sistem secara fungsional menjelaskan proses-proses logika atau fungsi.

\section{b) Analisis Keluaran}

Berisi mengenai gambaran keluaran yang dihasilkan oleh sistem yang dianalisa.

\section{c) Analisis Masukan}

Berisi mengenai gambaran masukan yang dihasilkan oleh sistem yang dianalisa.

\section{d) Identifikasi Kebutuhan}

Berisi mengenai identifikasi kebutuhan / usulan yang diperlukan oleh sistem berdasarkan hasil analisis keluaran dan masukan sistem yang berjalan pada ASIA Group Pangkalpinang.

\section{e) Use Case Diagram}

Use Case Diagram ini juga mendeskripsikan apa yang akan dilakukan oleh sistem.

\section{f)Package Diagram}

Penulis mengelompokkan elemen-elemen model dari Use Case Diagram.

\section{3) Perancangan Sistem}

Dalam perancangan suatu sistem informasi langkah yang perlu dilakukan diantaranya adalah perancangan sistem. Pada bab ini akan dibahas bagaimana perancangan dari sistem informasi yang akan dibangun.

\section{a) Rancangan Basis Data}

Penulis menggunakan Entity Relationship Diagram, dimana Entity Relationship Diagram memodelkan data apa yang ada, tujuan utama dari penggambaran ERD adalah menunjukkan objek data (entitas) dan hubungannya (relationship) terhadap entitas yang ada sehingga dapat dihasilkan file-file yang akan dibentuk.

b) Class Diagram

Class Diagram menggambarkan struktur dan hubungan antar objek-objek yang ada pada sistem.

\section{c) Deployment Diagram}

Deployment Diagram menggambarkan rinci bagaimana komponen di-deploy dalam infrastruktur 
sistem, dimana komponen akan terletak bagaimana kemampuan jaringan pada lokasi tersebut.

\section{d) Sequence Diagram}

Sequence diagram merupakan gambaran interaksi antar masing-masing objek pada setiap use case dalam urutan waktu.

\section{B. Metode Berorientasi Objek}

Metode pengembangan perangkat lunak yang di gunakan adalah pendekatan dengan Object Oriented yang menggunakan OOA (Object Oriented Analysis) dan OOD (Object Oriented Design) yang di visualisasikan dengan UML dan di antara nya adalah sebagai berikut : Activity Diagram, Use Case Diagram, Package Diagram, Class Diagram, Deployment Diagram, dan Sequence Diagram.

\section{Tools Pengembangan Sistem}

Penulis menggunakan UML (Unified Modelling Language) sebagai tools untuk perancangan dan pengembangan aplikasinya. Adapun tools UML (Unified Modelling Language) yang penulis gunakan dalam pengembangan sistem ini terdiri dari :
a. Activity Diagram
b. Use Case Diagram
c. Package Diagram
d. Class Diagram
e. Deployment Diagram
f. Sequence Diagram

\section{Langkah-Langkah Penelitian}

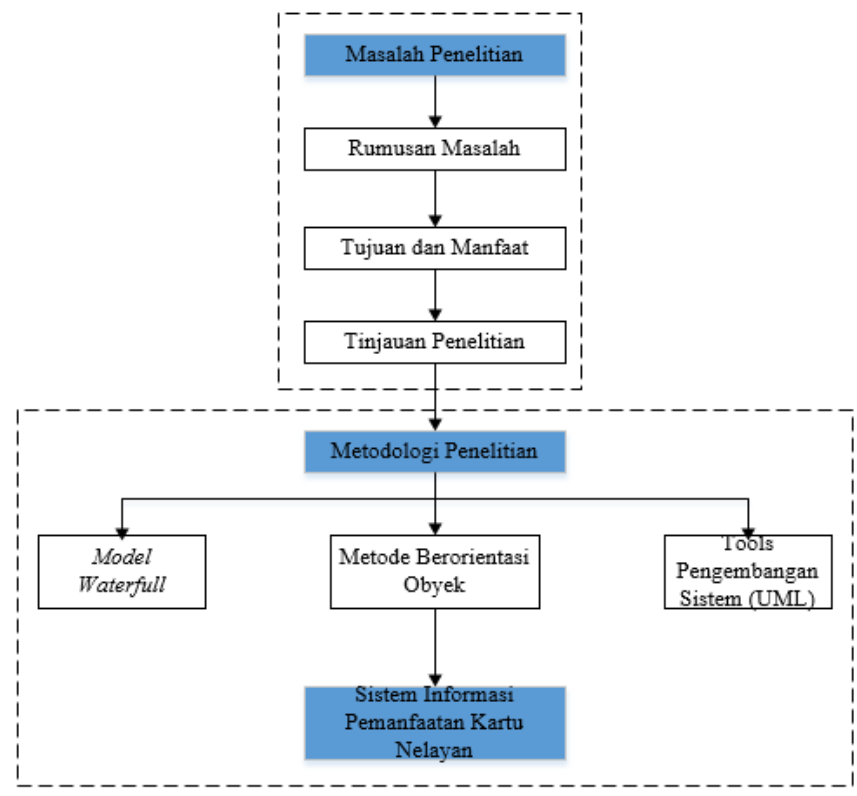

Gambar 2. Langkah-Langkah Penelitian

\section{HASIL DAN PEMBAHASAN}

\section{A. Sejarah Singkat Kabupaten Bangka Barat}

Kabupaten Bangka Barat merupakan kabupaten yang memiliki wilayah pesisir yang cukup luas di Propinsi Kepulauan Bangka Belitung, dengan panjang pantai $278,75 \mathrm{~km}$ maka luas wilayah laut Kab. Bangka Barat $\pm 1.541,29 \mathrm{~km} 2$ atau $154,129 \mathrm{Ha}$.

Dinas Kelautan dan Perikanan Kab. Bangka Barat mempunyai tugas pokok melaksanakan kewenangan otonomi daerah di bidang kelautan dan perikanan meliputi pengelolaan sumber daya perikanan dan kelautan, pesisir dan pulau-pulau kecil dalam rangka melaksanakan tugas desentralisasi dan tugas pembantuan.

\section{B. Proses Bisnis}

Prosedur yang dilakukan dalam Evaluasi Analisis dan Perancangan Sistem Informasi Pemanfaatan Kartu Nelayan Untuk Masyarakat Kabupaten Bangka Barat, Studi Kasus Dinas Kelautan dan Perikanan Kabupaten Bangka Barat sebagai berikut :

a. Pendataan Individu

Nelayan Individu nelayan datang ke Dinas Kelautan dan Perikanan untuk melakukan pengisian data kartu nelayan dengan menyerahkan Surat Keterangan Kepala Desa yang menyatakan individu nelayan tersebut benar adalah nelayan, selanjutnya Bidang Perikanan Tangkap menerima data yang telah diserahkan.

b. Proses Verifikasi Data

Staf Bidang Perikanan tangkap akan melakukan survey ke lapangan untuk kebenaran data yang telah diisi individu nelayan. Selanjutnya akan dibuatkan lembar verifikasi rekomendasi kartu nelayan.

c. Proses Penyerahan Kartu Nelayan

Setelah semua data diterima, masing-masing individu nelayan akan membuat Surat Pernyataan permohonan kartu nelayan dan selanjutnya Kartu Nelayan akan diserahkan kepada masing-masing individu nelayan.

d. Proses Kepersetaan Asuransi Nelayan

Individu nelayan datang ke Bidang Perikanan Tangkap dengan menyerahkan seluruh data untuk pengajuan kepersetaan asuransi nelayan. Setelah formulir kepersetaan asuransi nelayan dan form penunjukan ahli waris diisi maka seluruh data diserahkan ke Bidang Perikanan tangkap. Jika seluruh data sudah lengkap dari Pihak Asuransi akan menyerahkan Kartu Asuransi kepada masing- masing individu nelayan.

e. Proses Klaim Asuransi

Individu nelayan dapat membuat klaim asuransi jika terjadi kejadian yang tak diinginkan dengan mengisi form klaim asuransi dan membuat Berita Acara Kejadian (BAK) yang disetujui oleh Kepala Dinas. Selanjutnya akan dikirimkan surat pengajuan Klaim Asuransi, dan juga dikirimkan surat pemberitahuan klaim asuransi kepada Pihak Asuransi. 


\section{Activity Diagram}

Alur kerja dan urutan aktivitas proses bisnis pemanfaatan kartu nelayan dapat dilihat dengan activity diagram yang digambarkan sebagai berikut:

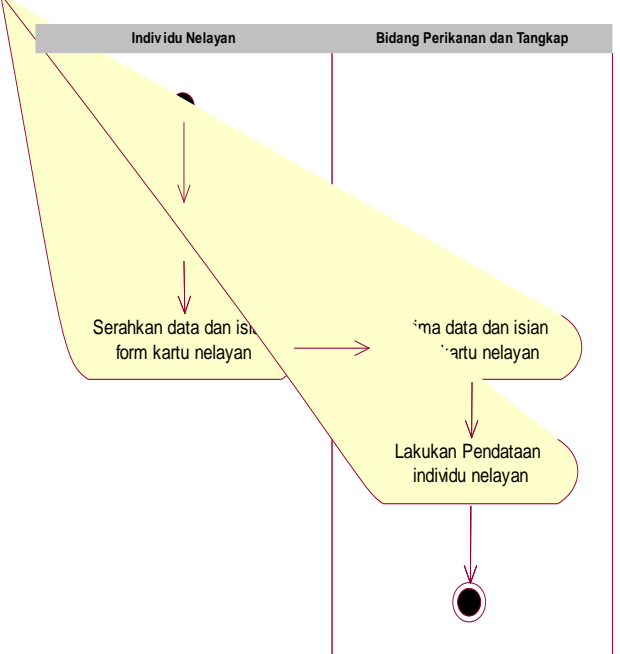

Gambar 3. Activity Diagram Pendataan Individu Nelayan

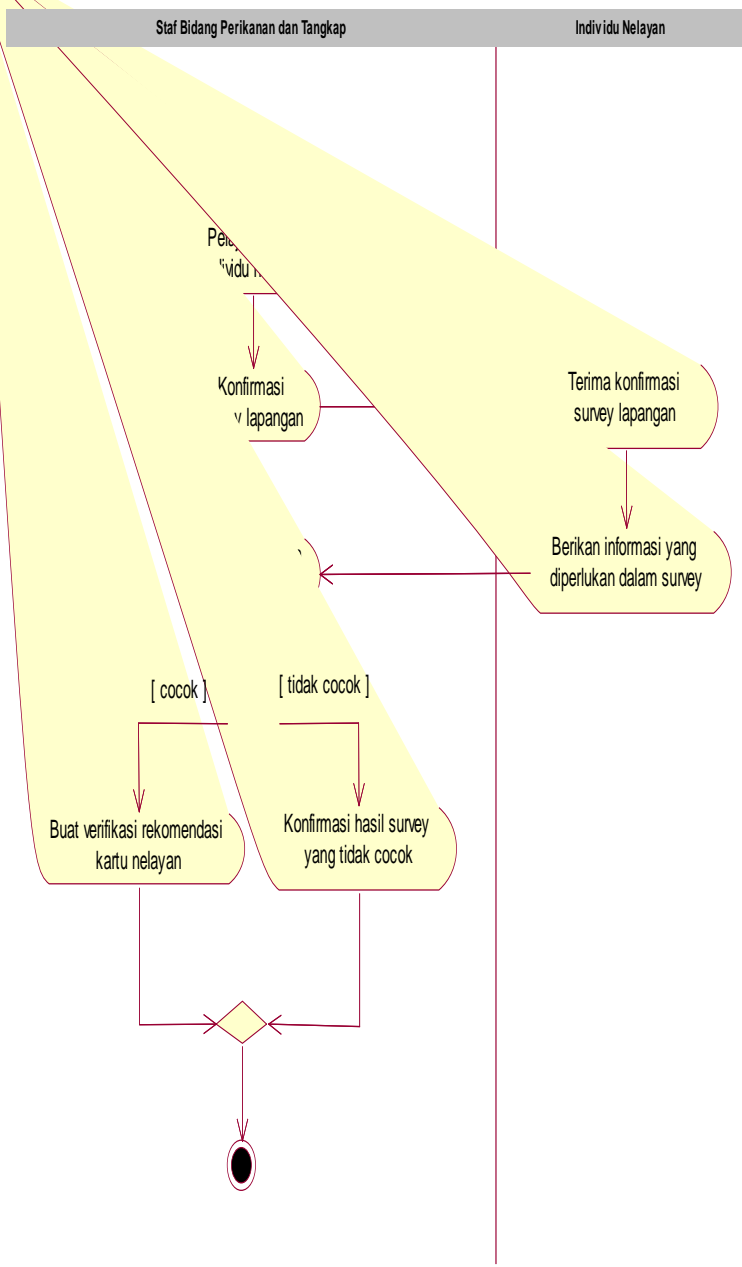

Gambar 4. Activity Diagram Proses Verifikasi Data

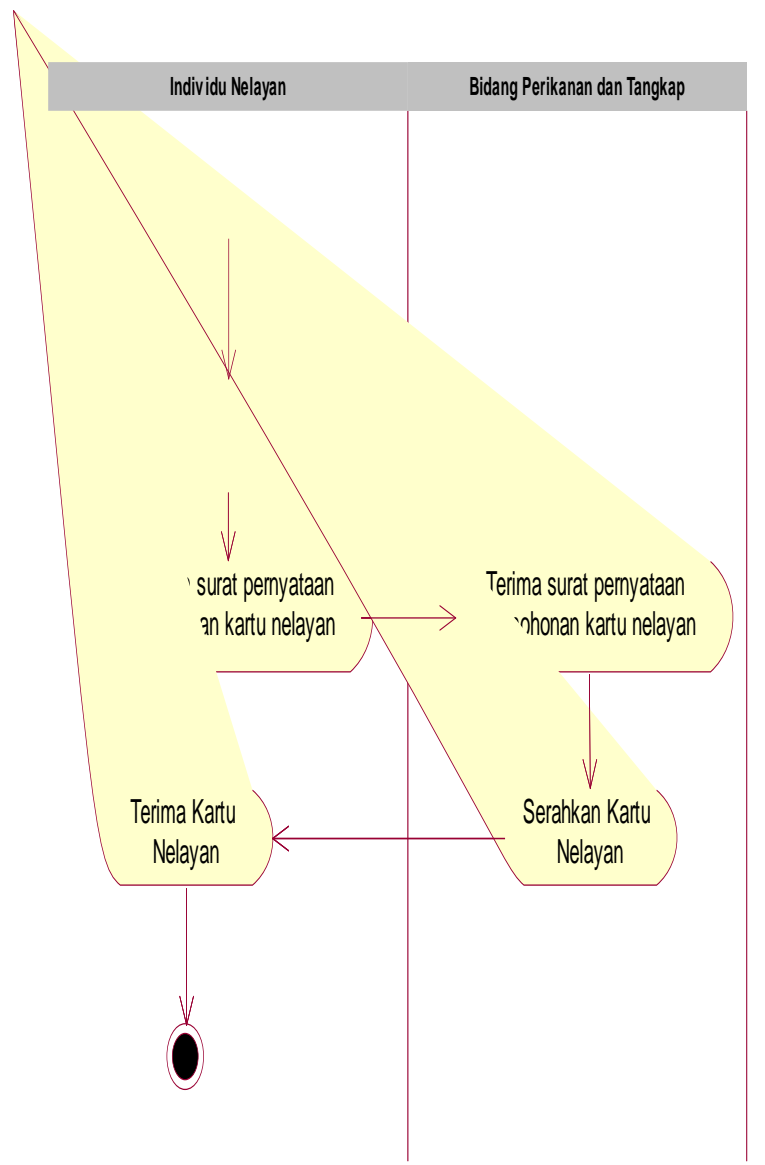

Gambar 5. Activity Diagram Proses Penyerahan Kartu Nelayan

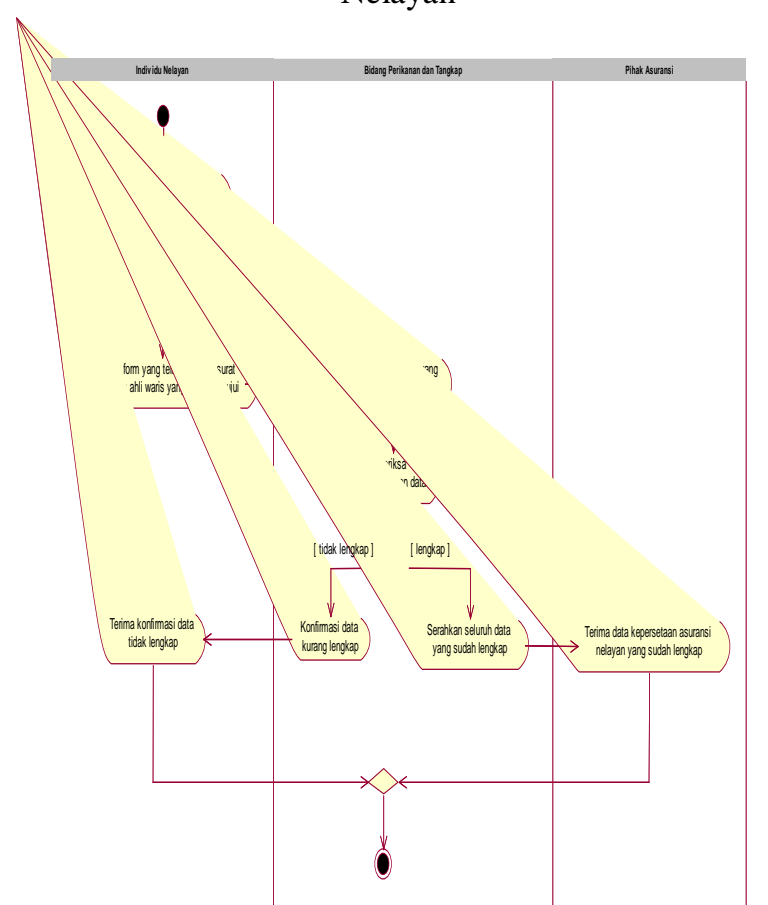

Gambar 6. Activity Diagram Proses Kepersetaan Asuransi Nelayan 
Jurnal SISFOKOM, Volume 06, Nomor 02, September 2017

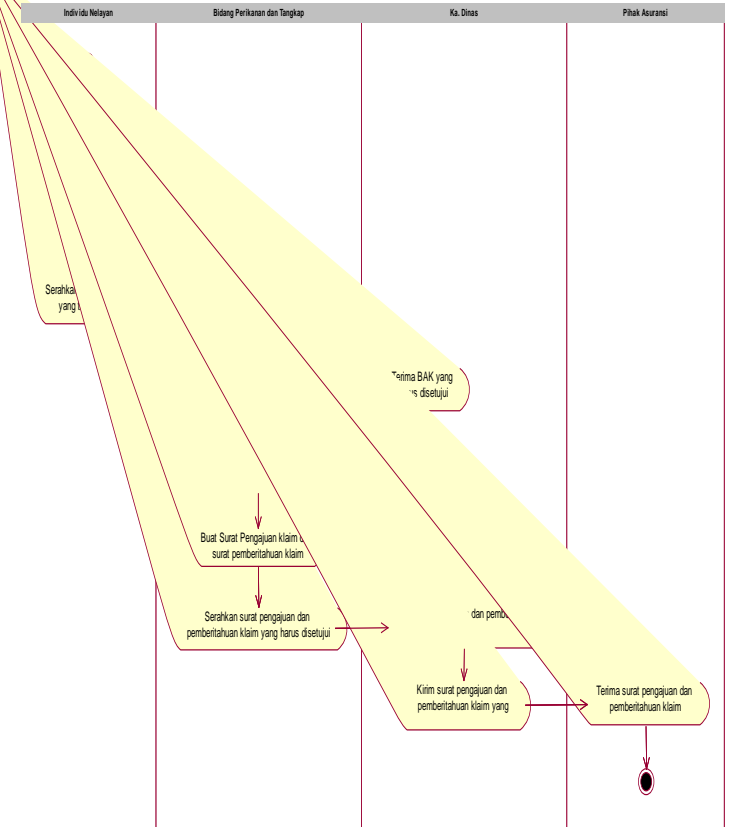

Gambar 7. Activity Diagram Proses Klaim Asuransi

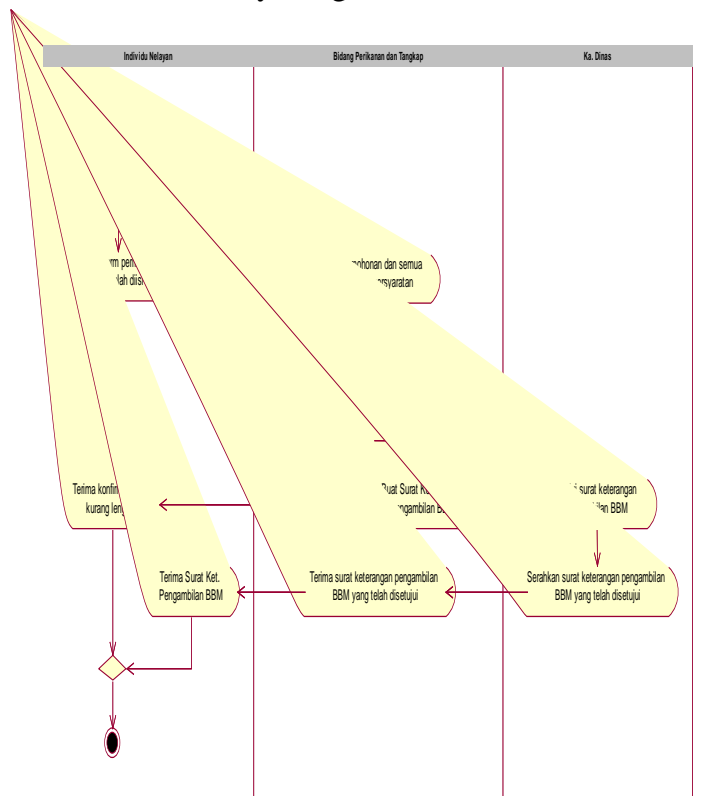

Gambar 8. Activity Diagram Proses Pengambilan BBM

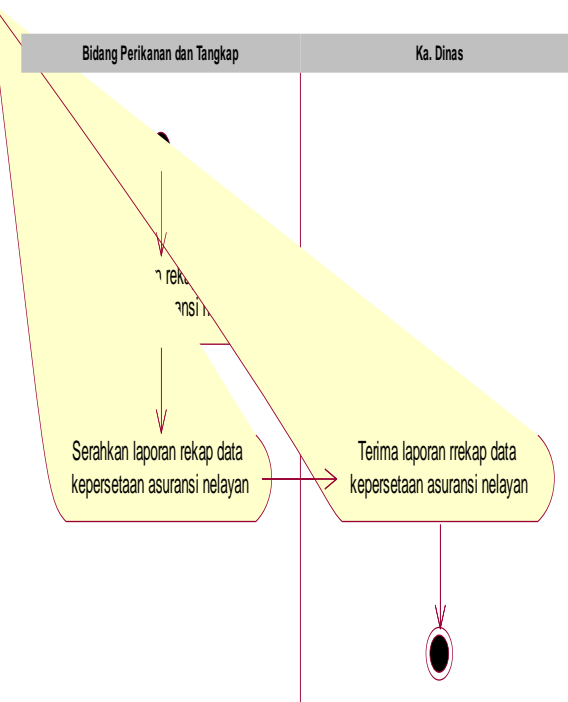

Gambar 9. Activity Diagram Proses Laporan Kepersetaan Asuransi Nelayan

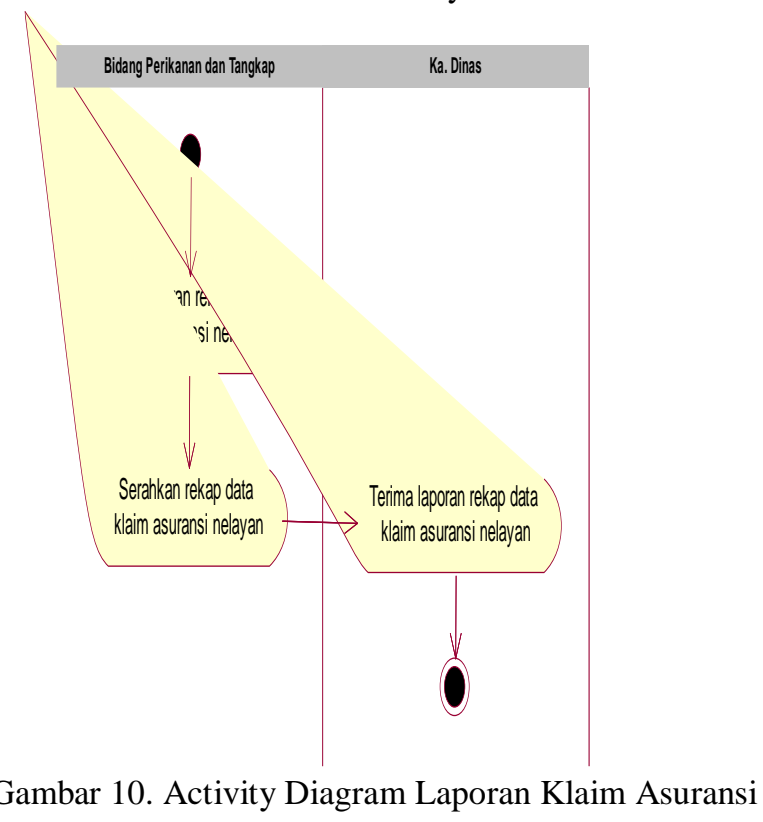




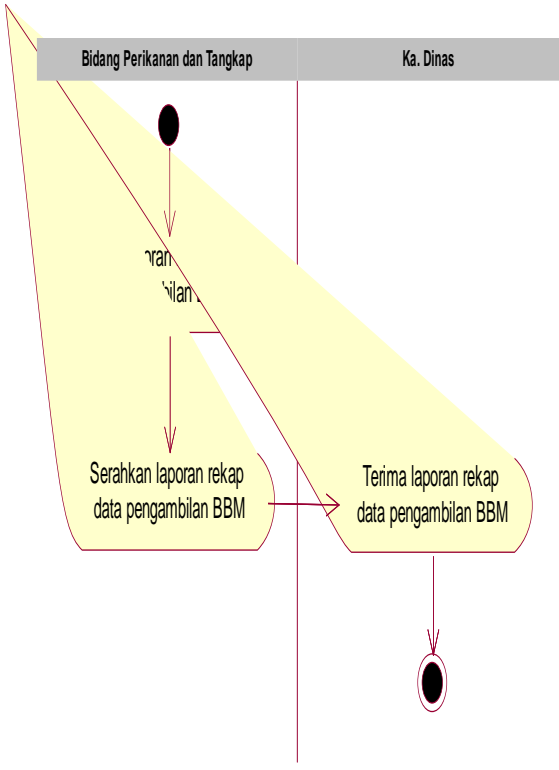

Gambar 11. Activity Laporan Pengambilan BBM

\section{Use Case Diagram}

Berikut ini adalah Use Case Diagram Analisis dan Perancanagan Sistem Informasi Kartu Nelayan Untuk Masyarakat Bangka Barat Berbasis Application Desktop Studi Kasus: Dinas Kelautan dan Perikanan Kabupaten Bangka Barat:

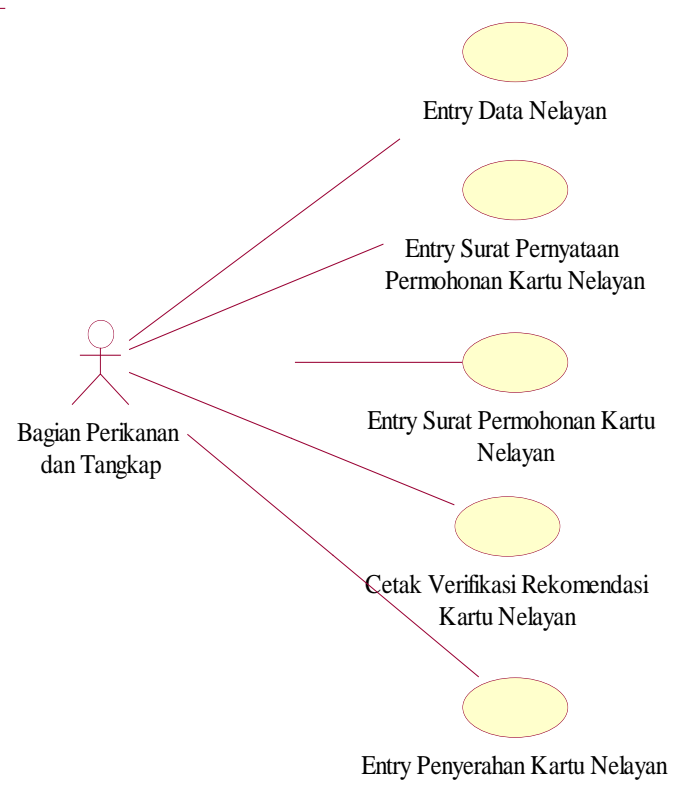

Gambar 12. Use Case Diagram Package Permohonan Kartu Nelayan

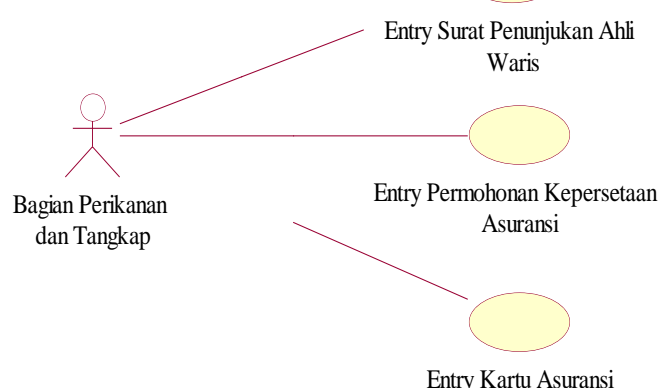

Gambar 13. Use Case Diagram Package Asuransi Nelayan

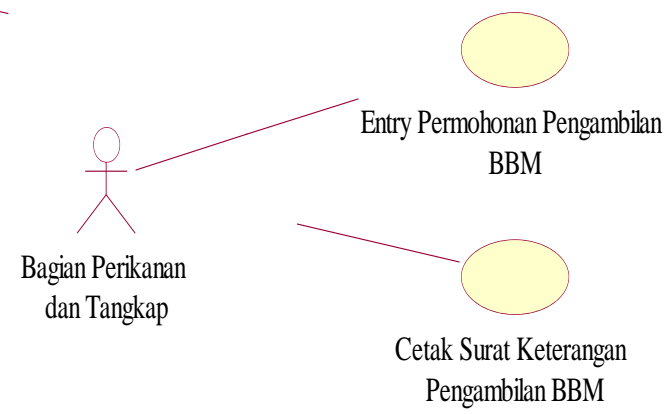

Gambar 14. Use Case Diagram Package Pengajuan BBM

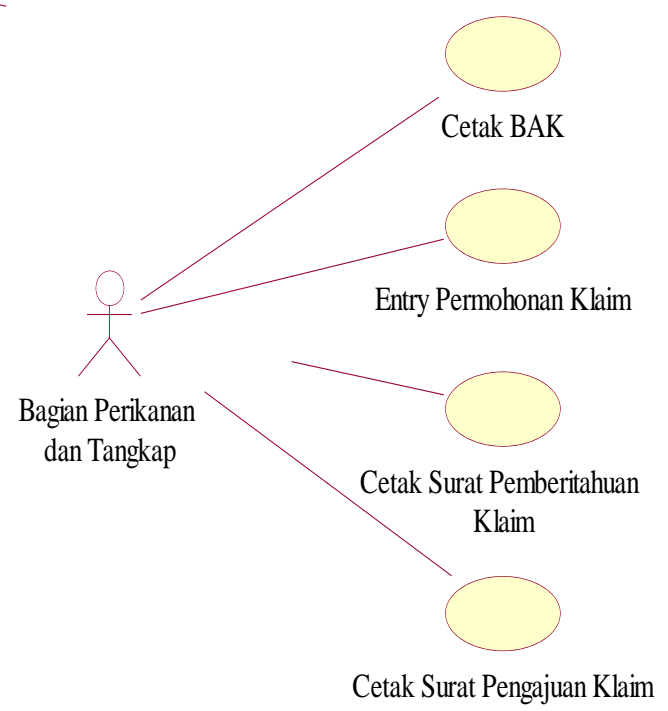

Gambar 15. Use Case Diagram Package Klaim Asuransi 

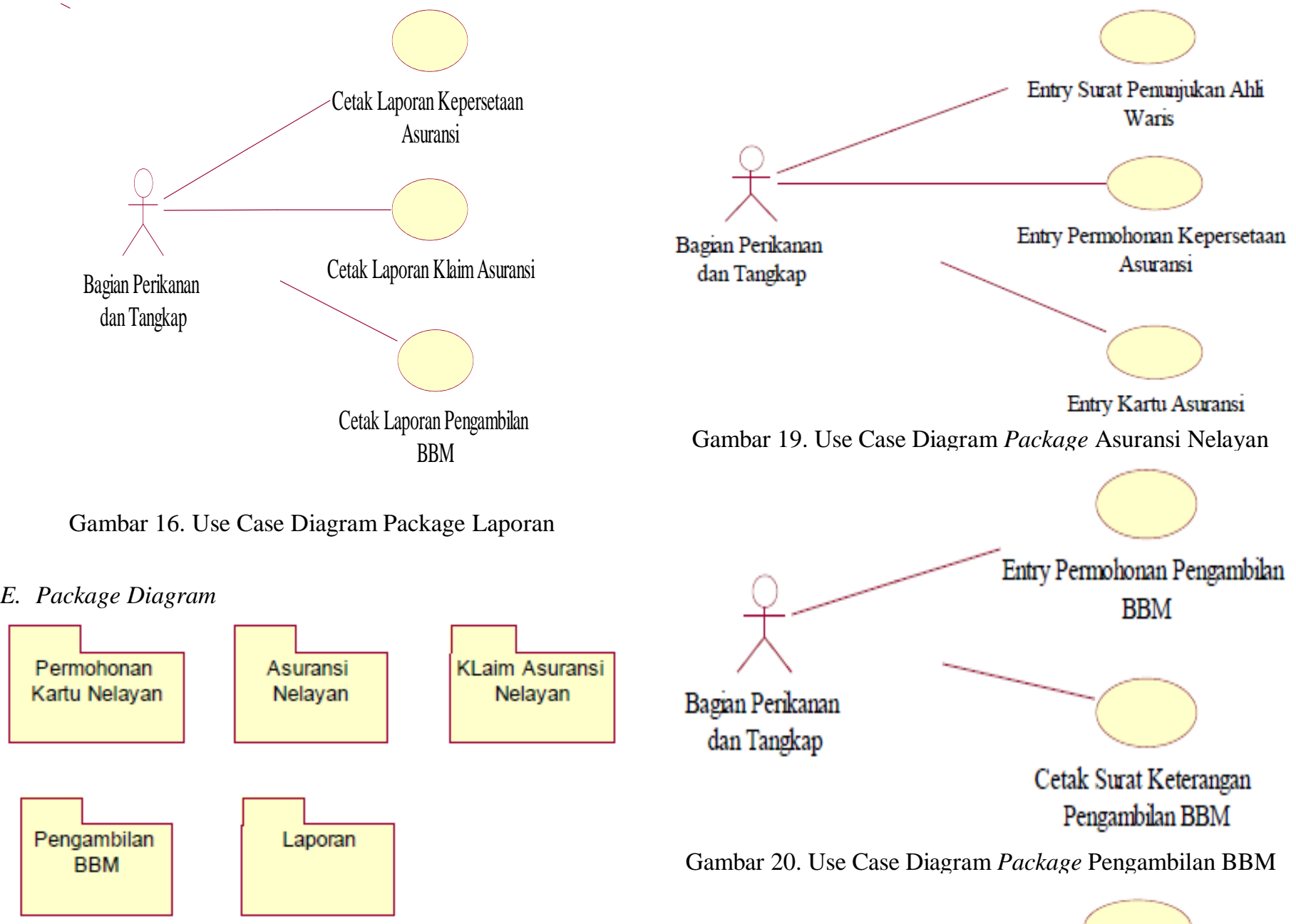

Gambar 19. Use Case Diagram Package Asuransi Nelayan

\section{E. Package Diagram}

Laim Asuransi

Gambar 17. Package Diagram

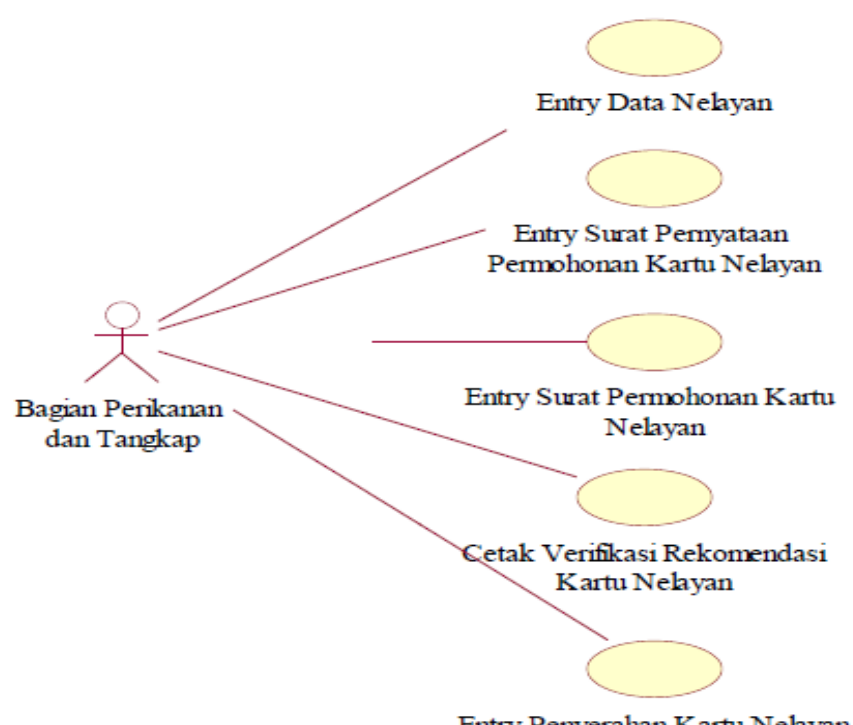

Entry Penyerahan Kartu Nelayan

Gambar 18. Use case Diagram Package Permohonan Kartu Nelayan

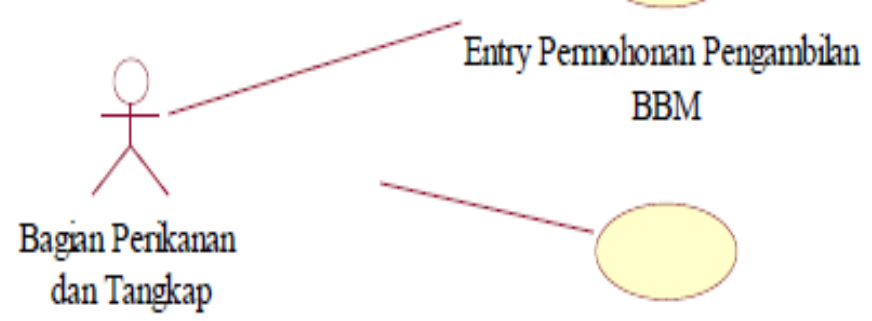

Cetak Surat Keterangan Pengambilan BBM

Gambar 20. Use Case Diagram Package Pengambilan BBM

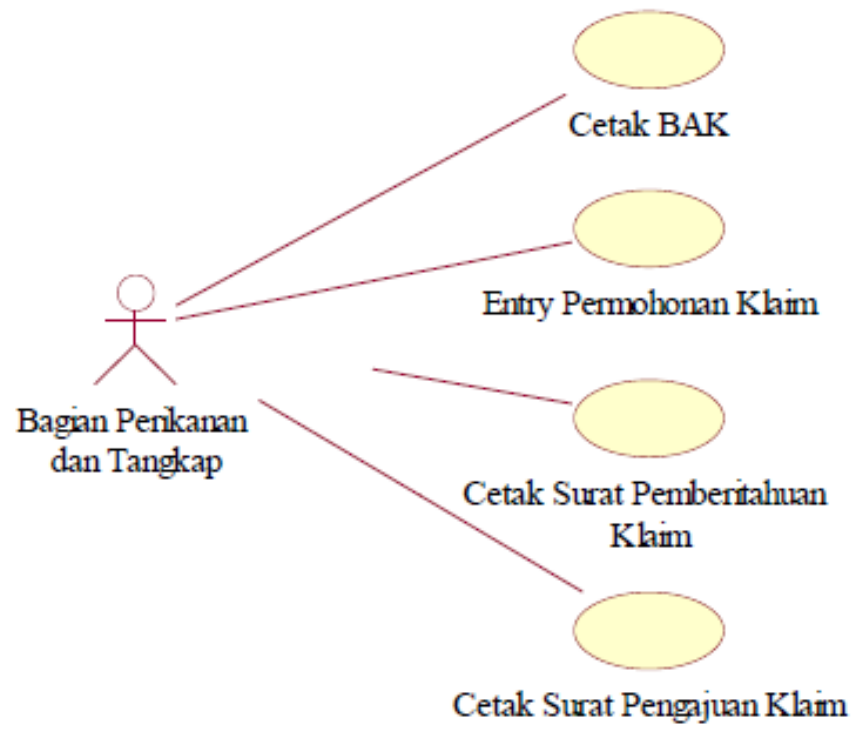

Gambar 21. Use Case Diagram Package Klaim Asuransi 


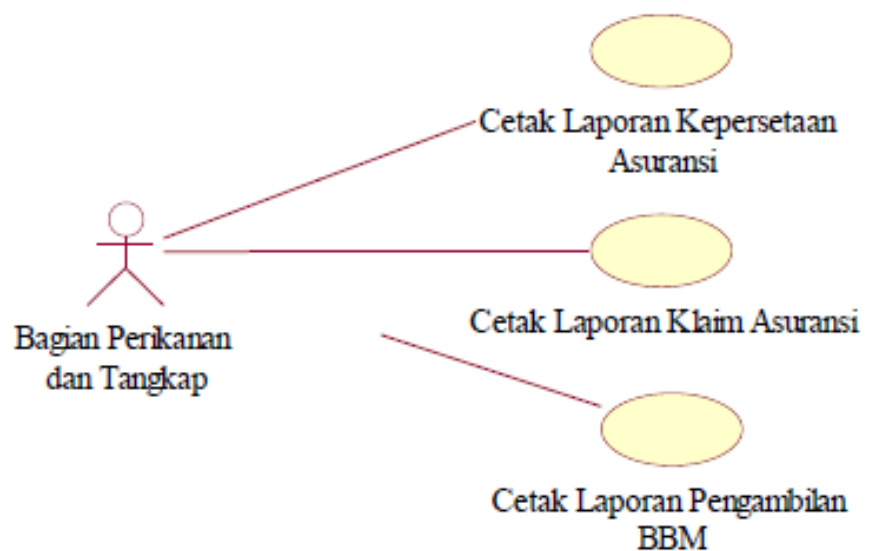

Gambar 22. Use Case Diagram Package Laporan

F. Entity Relationship Diagram (ERD)

Berikut ini adalah penjelasan dari Entity Relationship Diagram (ERD) :

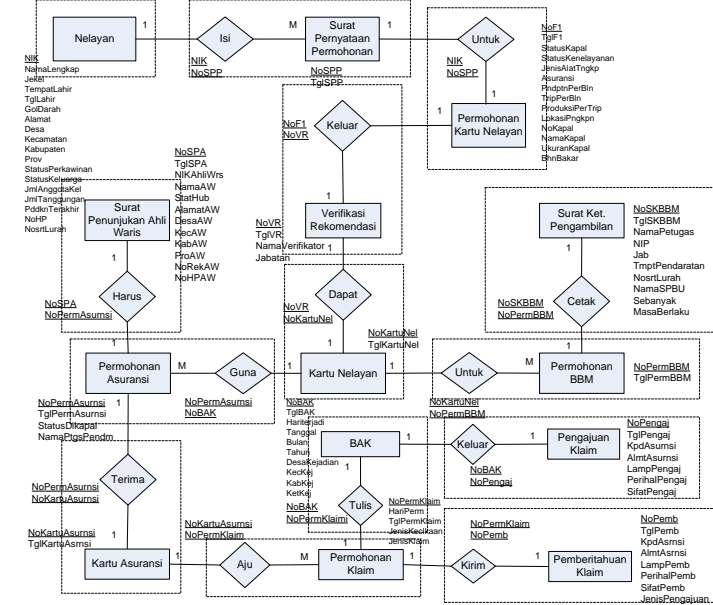

Gambar 23.Entity Relationship Diagram (ERD)

\section{G. Logical Record Structure (LRS)}

Berikut ini adalah penjelasan dari Logical Record Structure (LRS):

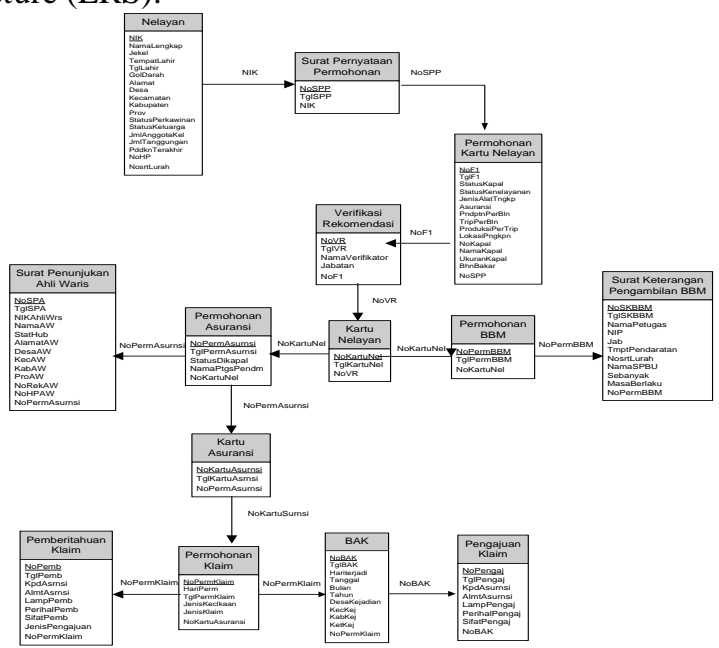

Gambar 24. Logical Record Structure (LRS)

\section{H. Rancangan keluaran}

Rancangan keluaran ini dimaksudkan memberi gambaran mengenai keluaran dari sistem informasi yang diusulkan. Rancangan keluaran yang dihasilkan pada Analisis dan Perancanagan Sistem Informasi Kartu Nelayan Untuk Masyarakat Bangka Barat Berbasis Application Desktop Studi Kasus: Dinas Kelautan dan Perikanan Kabupaten Bangka Barat adalah sebagai berikut :
1) Verifikasi Rekomendasi Kartu Nelayan.
2) Berita Acara Kejadian (BAK)
3) Surat Pengajuan Klaim
4) Surat Pemberitahuan Klaim
5) Surat Pengambilan BBM

\section{Rancangan Masukan}

Rancangan masukan yang dihasilkan pada Analisis dan Perancanagan Sistem Informasi Kartu Nelayan Untuk Masyarakat Bangka Barat Berbasis Application Desktop Studi Kasus: Dinas Kelautan dan Perikanan Kabupaten Bangka Barat adalah sebagai berikut :
1) Data Nelayan
2) Data Surat Pernyataan
3) Data Penerima Kartu Nelayan
4) Data Permohonan Kepersertaan Asuransi
5) Data Penunjukan Ahli Waris
6) Data Penerima Kartu Asuransi
7) Data Permohonan Klaim
8) Data Permohonan Pengambilan BBM

\section{J. Rancangan Antar Muka}

Berikut ini merupakan beberapa rancangan antarmuka Analisis dan Perancanagan Sistem Informasi Kartu Nelayan Untuk Masyarakat Bangka Barat Berbasis Application Desktop Studi Kasus: Dinas Kelautan dan Perikanan Kabupaten Bangka Barat:

a. Tampilan Layar Menu Permohonan Kartu Nelayan

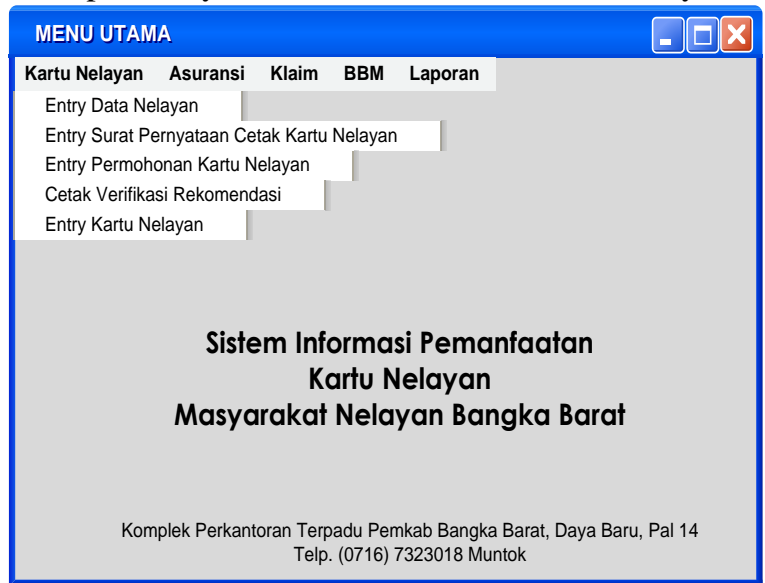

Gambar 25. Tampilan Layar Menu Permohonan Kartu Nelayan 
b. Tampilan Layar Menu Permohonan Kartu Nelayan MENU UTAMA

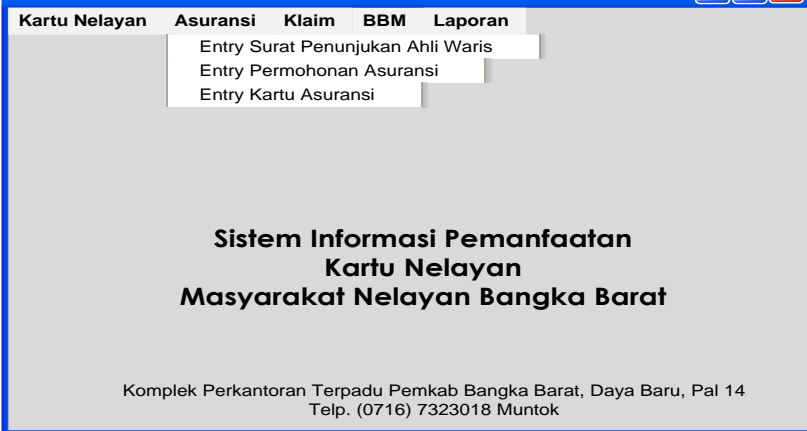

Gambar 26. Tampilan Layar Menu Kepersertaan Asuransi

c. Tampilan Layar Menu Permohonan Klaim

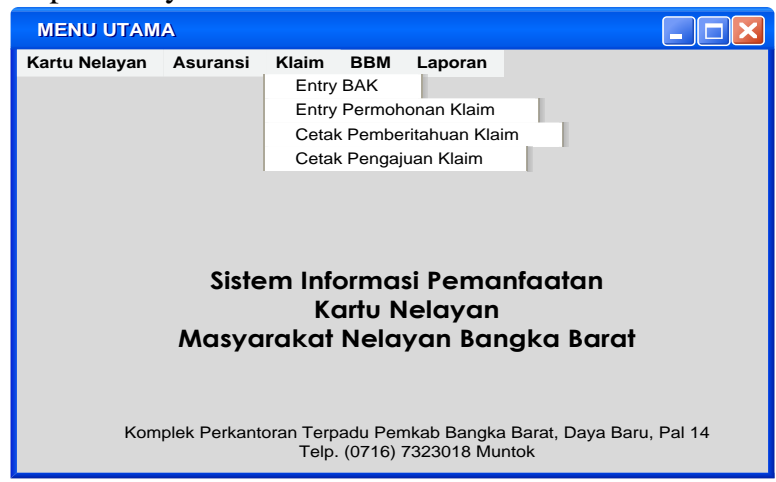

Gambar 27. Tampilan Layar Menu Permohonan Klaim

d. Tampilan Layar Menu Permohonan BBM

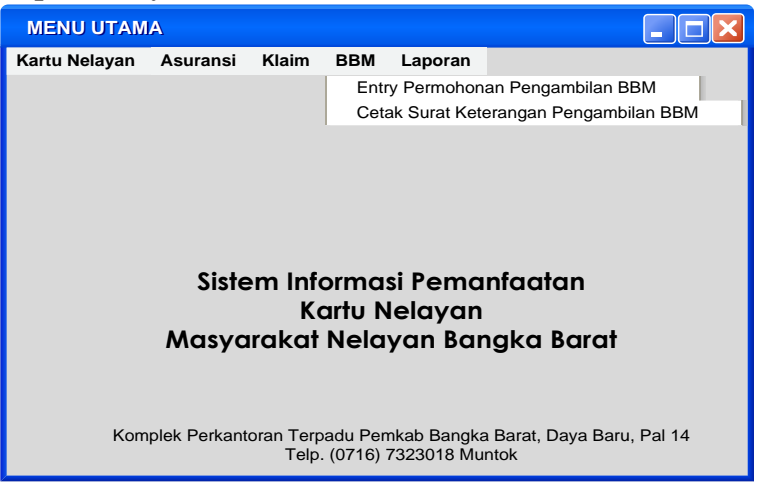

Gambar 28. Tampilan Layar Menu Permohonan BBM

e. Tampilan Layar Menu Laporan

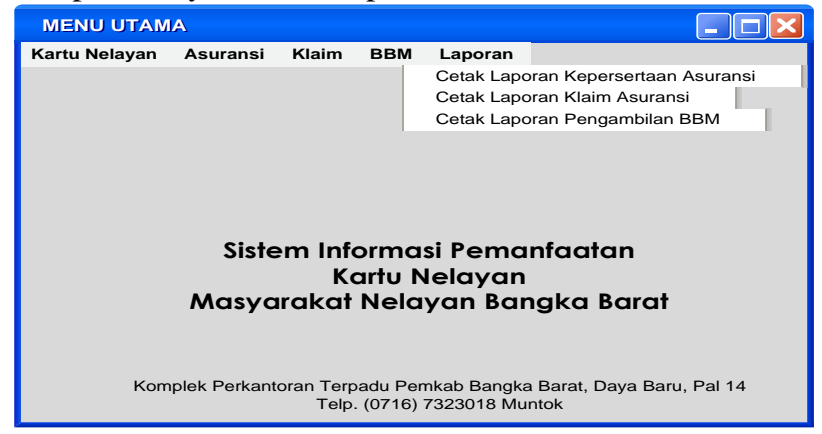

Gambar 29. Tampilan Layar Menu Laporan

\section{PENUTUP}

\section{A. Kesimpulan}

- Sistem Informasi Pemanfaatan Kartu Nelayan ini terintegrasi dan sangat mendukung penyimpanan seluruh data, mudah diolah, mudah diambil kembali datanya untuk keperluan proses bisnis selanjutnya yang dapat memberikan informasi yang dapat dijadikan sebagai dasar dalam pengambilan keputusan selanjutnya.

- Sistem Informasi Pemanfaatan Kartu Nelayan ini dapat memberikan kemudahan bagi Bidang Perikanan dan Tangkap dalam melakukan pengolahan data pemanfaatan kartu nelayan dengan cepat dan mudah.

- Sistem Informasi Pemanfaatan Kartu Nelayan ini dapat memberikan kemudahan bagi Bidang Perikanan dan Tangkap dalam melakukan pengolahan data kepersertaan asuransi dengan cepat dan mudah.

- Sistem Informasi Pemanfaatan Kartu Nelayan ini dapat memberikan kemudahan bagi Bidang Perikanan dan Tangkap dalam melakukan pengolahan data klaim asuransi dengan cepat dan mudah.

- Sistem Informasi Pemanfaatan Kartu Nelayan ini dapat memberikan kemudahan bagi Bidang Perikanan dan Tangkap dalam melakukan pengolahan data Pemngambilan BBM dengan cepat dan mudah.

- Sistem Informasi Pemanfaatan Kartu Nelayan ini dapat memberikan kemudahan bagi Bidang Perikanan dan Tangkap dalam pembuatan laporan dengan cepat dan mudah.

\section{B. Saran}

- Perlu adanya pelatihan terhadap user yang akan menggunakan sistem informasi ini, agar user dapat mengetahui cara penggunaan dan perawatan sistem informasi ini.

- Perlu adanya peningkatan infrastruktur komputer yang digunakan, agar dapat terciptanya efisien dan efektivitas yang lebih dalam rangka mendukung sistem informasi ini.

- Untuk menghindari berbagai kesalahan yang mungkin timbul pada sistem, perlu dilakukan perawatan (maintenance) secara rutin. Pengontrolan akses pengguna (user) juga perlu diperhatikan yang merupakan salah satu cara perawatan yang tebaik untuk menghindari berbagai kesalahan dalam penggunaan sistem.

- Secara rutin perlu dilakukan dalam back-up data yang ada untuk menghindari kerusakan data atau kehilangan data yang merupakan salah satu dalam penyelamatan data pemanfaatan kartu nelayan.

- Spesifikasi Komputer (hardware dan software) perlu diperhatikan dalam implementasi sistem yang akan digunakan pengguna sistem agar sistem dapat berjalan sebagaimana mestinya. 


\section{DAFTAR PUSTAKA}

[1] Tata Sutabri, 2012, Analisis Sistem Informasi Yogyakarta: CV. Andi Offset.

[2] Edhy Sutanta, 2011, Basis Data dalam Tinjauan Konseptual Yogyakarta: CV. Andi Offset.

[3] Jogiyanto Hartono, Mustakini, 2010, Metode Penelitian Sistem Informasi. Yogyakarta: Andi Offset.

[4] Indrajani, 2009 Pengantar dan Sistem Basis Data Jakarta: PT Elex Media Komputindo.

[5] Fathansyah, 2007, Buku Teks Komputer Basis Data Bandung: Informatika Bandung.

[6] Adi Nugroho. 2010, Rekayasa Perangkat Lunak Menggunakan UML \& Java, Yogyakarta: Andi Offset

[7] Edy Winarno, Step by Step Visual Basic.Net. Jakarta: PT. Elex Media Komputindo, 2012

[8] Yunia Faizah Arsy, 2014, Strategi Pembiayaan Pada Masyarakat Nelayan dalam Mendukung Usaha Perikanan Tangkap di PPI Muara Angke, Skripsi, Program Sarjana Perikanan, Fakultas Perikanan dan Ilmu Kelautan Institut Pertanian Bogor.

[9] Vivi Christovani Mawuntu, 2015, Profil Perikanan Tangkap

dan Strategi

Pengelolaan Sumberdaya Perikanan Tangkap di Karimunjawa, Jawa Tengah, Skripsi, Program Sarjana Fakultas Ekonomika dan

Bisnis Universitas Diponegoro.

[10] Vivi Christovani Mawuntu, 2015, Strategi Kebijakan Pemerintah Dalam Upaya Peningkatan Pendapatan Nelayan (Studi kasus pada Dinas Kelautan, Perikanan dan Pengelola Sumber Daya Kawasan Segara Anakan Kabupaten Cilacap), Skripsi, Fakultas Ekonomi dan Bisnis Islam Institut Agama Islam Negeri Purwokerto.

[11] Wahyudin, Metode Pengembangan Perangkat Lunak,http://file.upi.edu/Direktori/FPMIPA/PRODI._IL MU_KOMPUTER/WAHYUDIN/Metode_Pengembanga n_PL.pdf, diakses tanggal 9 Mei 2017

[12] Ahmad Zainuri, Ulil Albab, Moh. Sholahuddin, 2009 Makalah Inheritance, Polymorphism,

[13] Enkapsulasi Universitas Lamongan Fakultas Teknik Informatika Kampus Pondok Pesantren Sunan Drajat Banjarwati Paciran Lamongan

[14] Meta, Alat Bantu Perancangan Sistem, 2015, https://kelompokalatbantuperancangan.wordpress.com/ diakses tanggaal 9 Mei 2017 